\title{
Floristic and structural status of forests in permanent preservation areas of Moju river basin, Amazon region
}

\author{
J. C. Oliveira ${ }^{a}$, I. C. G. Vieira ${ }^{a *}$, A. S. Almeida ${ }^{a}$ and C. A. Silva Junior ${ }^{a}$ \\ ${ }^{a}$ Coordenação de Botânica, Museu Paraense Emílio Goeldi, Av. Perimetral, 1901, Bairro Terra Firme, \\ CEP 66077-530, Belém, PA, Brazil \\ *e-mail: ima@museu-goeldi.br
}

Received: March 20, 2015 - Accepted: August 10, 2015 - Distributed: November 30, 2016

(With 5 figures)

\begin{abstract}
The goal of this study is to analyze the floristic patterns and the structure of disturbed and undisturbed upland forests, in Permanent Preservation Areas (PPAs) along the Moju river, in the Brazilian state of Pará. Trees with a diameter equal to or larger than $10 \mathrm{~cm}$ at $1.30 \mathrm{~m}$ from the ground $(\mathrm{DBH}) \geq 10 \mathrm{~cm}$ were analyzed for the upper stratum. For the middle stratum, individuals with DBH between 4.99 and $9.99 \mathrm{~cm}$ were sampled. Forty-five families and 221 species were found in disturbed forests, and 43 families and 208 species in undisturbed forests. Floristic similarity was high between strata and between forest types, with values above 50\%. Similarity was highest between middle strata. The most species-abundant families in undisturbed forests were Fabaceae, Sapotaceae, Chrysobalanaceae and Myrtaceae; the species with the highest density there were Eschweilera grandiflora, Licania sclerophylla and Zygia cauliflora. In disturbed forests, the dominant families were Fabaceae, Sapotaceae, Lecythidaceae and Melastomataceae. The Shannon-Wiener diversity index was 3.21 for undisturbed forests and 2.85 for disturbed forests. Non-metric multidimensional scaling (MDS) analysis did not group the forests by their floristic composition in both upper and middle strata. Overall, the PPA forests along the Moju river, even if disturbed, did not show major floristic changes but substantially change their structural characteristics.
\end{abstract}

Keywords: remnant forests, Amazon, forest degradation.

\section{Comparação florística e estrutural de florestas em áreas de preservação permanente do rio Moju, região Amazônica}

\section{Resumo}

Este estudo teve como objetivo analisar os padrões florísticos e a estrutura de florestas ripárias perturbadas e não perturbadas inseridas em Áreas de Preservação Permanente ao longo do rio Moju, Pará. A análise do estrato superior foi realizada em árvores com diâmetro a $1,30 \mathrm{~m}$ do solo (DAP) $\geq 10 \mathrm{~cm}$. No estrato médio, amostrou-se os indivíduos com DAP entre 4,99 e 9,99 cm DAP. Nas florestas perturbadas foram encontradas 45 famílias e 221 espécies e nas florestas não perturbadas, 43 famílias e 208 espécies. A similaridade florística foi elevada entre os estratos e entre os tipos de florestas, alcançando valores maiores de que 50\%. A maior semelhança foi encontrada entre os estratos médios. As famílias mais abundantes em espécies nas florestas não perturbadas foram Fabaceae, Sapotaceae, Chrysobalanaceae e Myrtaceae. As espécies com maiores densidades foram Eschweilera grandiflora, Licania sclerophylla e Zygia cauliflora. Nas florestas perturbadas, as famílias dominantes foram Fabaceae, Sapotaceae, Lecythidaceae e Melastomataceae. A diversidade (Shannon) nas florestas não perturbadas foi de 3,21, e nas florestas perturbadas, alcançaram 2,85. A ordenação feita pelo escalonamento multidimensional MDS, não agrupou as florestas por sua composição florística, tanto no estrato superior como no médio. Em geral, as florestas perturbadas das APPs do rio Moju, mesmo se perturbadas, não evidenciam grandes mudanças florísticas, mas apresentam alterações nas suas características estruturais.

Palavras-chave: florestas remanescentes, Amazônia, degradação florestal.

\section{Introduction}

Riparian forests in Amazonia are plant formations with a floristic composition and vegetation structure quite similar to those of upland forest areas, and are therefore considered as such. They are located along the edges of water courses and perform an important environmental role, mainly in the prevention of soil erosion and stilting of rivers, maintaining water quality and contributing to the preservation of biodiversity. Brazilian law considers 
them Areas of Permanent Preservation (PPAs, or APPs in Portuguese) (Brasil, 2002).

The concept of Permanent Preservation Areas in the Forest Law of 1965 emerged to ensure the integrity of the vegetation for maintaining the physical and biological equilibrium in Brazilian biomes. These are areas exclusively for preservation and cannot be utilized for agricultural or farming activities, forest extraction or recreational uses (Sparovek et al., 2011). Despite being protected by law, these forests are widely threatened in Brazil by deforestation and anthropogenic activities. In Moju municipality, Pará state, $29.3 \%$ of the PPAs were disturbed by land uses and the application of the new Brazilian Forest Code will result in the loss of $\approx 60 \%$ of forest vegetation from the PPAs in this county (Almeida and Vieira, 2014). The conservation role of PPAs presumably increases in highly deforested regions, such as the Belém Area of Endemism, that has reached at least $75 \%$ of the original extent and further extensive forest loss (Almeida and Vieira, 2010; Amaral et al., 2012).

It is therefore of foremost importance to develop studies describing the plant communities of those protected areas in order to provide a picture of the remaining biodiversity and its distribution in the landscape. Lack of studies on floristic composition, structure and conservation status of PPAs, allied to social and environmental problems in Amazonia have hindered the adoption of practices towards the restoration and conservation of those areas of permanent preservation. Within this context, this study aims at analyzing and comparing floristic diversity and structure of forests with different status of conservation in Permanent Preservation Areas in the municipality of Moju, state of Pará, and discuss their importance for the conservation and restoration of those areas.

\section{Material and Methods}

\subsection{Study area}

The study was conducted in the municipality of Moju, eastern Pará, Brazil, in Permanent Preservation Areas of rural properties in the Moju river basin $\left(01^{\circ} 26^{\prime} 31.7^{\prime \prime}-02^{\circ} 24^{\prime} 31.3\right.$ 'S and $\left.048^{\circ} 26^{\prime} 54.2^{\prime \prime}-048^{\circ} 59^{\prime} 21.8^{\prime \prime} \mathrm{W}\right)$. Local climate is of the type Ami, according to Köppen's classification (Nascimento and Homma, 1984). Average annual temperatures are high, varying between $25^{\circ} \mathrm{C}$ and $27^{\circ} \mathrm{C}$. Annual rainfall is between $2000 \mathrm{~mm}$ and $3000 \mathrm{~mm}$, irregularly distributed, being more concentrated (about $80 \%$ ) from January to July; however, a short period of drought usually occurs between September and November. Relative air humidity is around $85 \%$ (Costa et al., 1998). Predominant soil types are Yellow Latosols of different textures, with Red-Yellow Podzols, Poorly Humic Gleysols and Plinthosols occurring as well (Santos et al., 1985; Costa et al., 1998). The original vegetation of this region of northeastern Pará, where the municipality of Moju is located, included extensive areas of ombrophilous dense forest (Rodrigues et al., 1997). The creation of the PA-150 highway led to intensive human occupation of the region with concomitant timber extraction and agricultural development such that by 2010 only $60 \%$ of its original vegetation cover remained, with much of this highly degraded (Almeida and Vieira, 2014). PPAs cover about $5 \%$ of the municipality of Moju, and are being subjected to strong pressures due to the expansion of agricultural activities and the cultivation of African oil palm (dendezeiro); some $28 \%$ of those PPAs are already in an illegal condition (Almeida and Vieira, 2014).

Location of PPA areas for this study was carried using satellite images followed by fieldwork. Area selection was conducted in the field, according to the following criteria: presence or absence of fire events and logging operations and availability of places authorised by community leaders in the municipality.

The selected areas were covered by upland ombrophilous dense forest (Pires, 1973), with a large number of $25-50 \mathrm{~m}$ tall trees (Serrão et al., 2003) in unflooded terrain of the riparian zone of Moju river. Two types of forest were identified according to conservation status: disturbed forest and undisturbed forest.

Disturbed forests within PPAs, in illegal condition vis-à-vis the Brazilian Forest Law, were defined as a result of a process of degradation caused by a selective extraction of timber and regular occurrence of fire (Nepstad et al., 1999). Conversely, undisturbed forests within PPAs were defined by the presence of well-established forest strata and absence of visible disturbance, as the occurrence of stumps and fire scars.

\subsection{Data collection and analysis}

Data was collected in 2011 in plots belonging to small farmers in six rural communities in the municipality of Moju: Vila Olho D’água, Vila Soledade, Vila São Jorge, Vila São Tomé, Vila São Pedro, Vila Braulande (Figure 1). In each rural community, one area of undisturbed forest and one of disturbed forest were selected along the riparian strip of the Moju river.

Two plots of $250 \mathrm{~m} \times 10 \mathrm{~m}\left(5000 \mathrm{~m}^{2}\right)$, located at least $40 \mathrm{~m}$ away from each other and positioned lengthwise along the river course, were established for each type of forest (disturbed and undisturbed). In total 12 plots per forest type were sampled, totaling 3 ha. The upper stratum, with trees of $\mathrm{DBH} \geq 10 \mathrm{~cm}$, was thoroughly surveyed. For the middle stratum, trees with $\mathrm{DBH} \geq 5.0 \mathrm{~cm}$ and $\leq 9.99 \mathrm{~cm}$ were inventoried in five subplots of $25 \mathrm{~m} \mathrm{x} 10 \mathrm{~m}\left(1250 \mathrm{~m}^{2}\right)$, randomly distributed within each plot. Palm trees forming a stool were considered as a single individual, of which the $\mathrm{DBH}$ of a single stipe was measured. Plant species were identified under field conditions by experienced parabotanists (Nelson Rosa and Carlos Alberto Silva) from the Museu Paraense Emílio Goeldi (MPEG). Voucher samples of specimens which defied confident field identification were collected and taken for comparison with reference material at the MG herbarium. Our taxonomy follow Haston et al. (2009).

To generate aerial biomass estimates (as Mg.ha-1) we used allometric equations for classes with $5 \mathrm{~cm} \leq$ $\mathrm{DBH}<20 \mathrm{~cm}$ and $\mathrm{DBH} \geq 20 \mathrm{~cm}$. Each tree was measured with an ordinary measuring tape in order to obtain $\mathrm{CBH}$ 


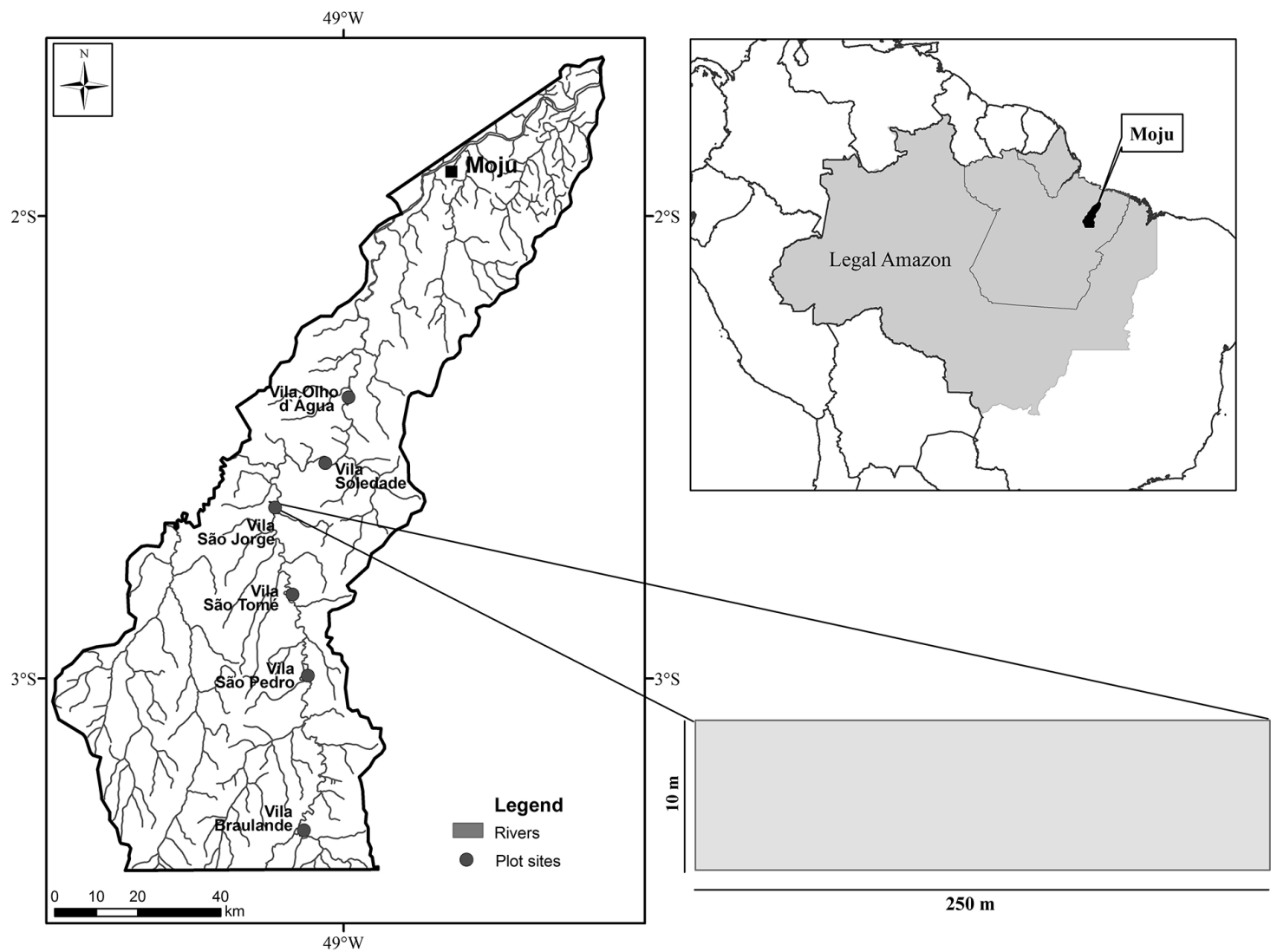

Figure 1. Location of study area, Moju, state of Pará, Amazon region.

values (circumference at $1.30 \mathrm{~m}$ from the ground), later converted into DBH. Total tree height was estimated in the field using a $5 \mathrm{~m}$ stick. Allometric equations following Higuchi et al. (1998) were generated by means of a consistent model with the lesser amplitude of standard deviation: $\mathrm{P}=0,0336 *\left(\mathrm{D}^{\wedge}(2,171)\right)^{*}\left(\mathrm{H}^{\wedge}(1,038)\right)$ for $5 \mathrm{~cm} \leq \mathrm{DBH}<20 \mathrm{~cm} ; \mathrm{P}=0,0009^{*}\left(\mathrm{D}^{\wedge}(1,585)\right)^{*}\left(\mathrm{H}^{\wedge}(2,651)\right)$ for $\mathrm{DBH} \geq 20 \mathrm{~cm}$, where: $\mathrm{P}=$ weight of fresh mass $(\mathrm{kg})$; $\mathrm{D}=$ diameter at $1.30 \mathrm{~m}$ from the ground $(\mathrm{DBH}) ; \mathrm{H}=$ total height. Student t-tests were used to compare diversity and biomass for undisturbed and disturbed forests, at a 5\% significance level. Distributions of DBH for each type of forest were tested for similarity with a Kolmogorov-Smirnov two-sample test (Sokal and Rohlf, 1995).

Floristic diversity for the upper and middle forest strata was calculated by Shannon-Wiener Diversity Index $\left(\mathrm{H}^{\prime}\right)$ and evenness (J') was calculated using Pielou Index (Magurran, 2004).The Sørensen diversity index was used to compare similarity between the strata (Mueller-Dumbois and Ellenber, 1974).The software Mata Nativa (Cientec, 2002) was used for analysis.

A multidimensional scaling analysis (MDS) was performed with the Systat 12.0 program to detect possible dissimilarities between the two forest types, from matrices of abundance of tree species in the upper and middle strata. The Bray-Curtis distance method was adopted for the quantitative data matrix (abundance). A similarity analysis (ANOSIM) was used, using the Bray Curtis distance with 999 permutations, to test the significance of the groups generated in the ordination. The ANOSIM was run in the program PRIMER v 6 (Clarke and Gorley, 2006).

\section{Results}

Considering all sampled plots and the upper and middle strata of the two types of forests, a total of 4227 individuals belonging to 47 families and 270 species were identified. Undisturbed forests accounted for 2060 individuals of 43 families and 208 species, and disturbed forests for 2167 individuals of 45 families and 221 species.

Families with the largest contribution to floristic richness in undisturbed forests were: Fabaceae, with 51 species (24.52\%); Sapotaceae, with 16 species $(7.69 \%)$; Chrysobalanaceae and Myrtaceae, with 12 species each $(5.77 \%)$. Families with the highest density were Fabaceae (718), Chrysobalanaceae (272) and Lecythidaceae (251), together making up for $60.24 \%$ (1241 individuals) of the total found in this forest type.

In disturbed forests, the most representative families in number of species were Fabaceae, with 50 species (22.62\%); Sapotaceae, with 14 species (6.33\%); Lecythidaceae and Melastomataceae, with 11 species each (4.98\%). 
The most abundant families there were also Fabaceae (633), Lecythidaceae (344) and Chrysobalanaceae (283), together representing $58.14 \%$ (1260 individuals) of the total found in disturbed forests.

In the upper stratum of undisturbed forests the family Fabaceae stood out in terms of species richness, as well as Lecythidaceae and Chrysobalanaceae, which also fared well in the upper stratum of disturbed forests. Fabaceae showed high values of species richness in any forest type. In the middle stratum, the families Fabaceae, Annonaceae and Melastomataceae made up $31.41 \%$ of its number of species. As for the environment where they occur, Fabaceae stood out in more preserved forests and again proved to be indifferent to disturbance.

The most abundant species in undisturbed forests (Table 1; Appendix 1) were Eschweilera grandiflora (Aubl.) Sandwith (151 individuals) and Licania sclerophylla (Hook. f.) Fritsch (90 individuals), while in disturbed forests they were also well represented (193 and 70 individuals respectively), as were also Licania heteromorpha Benth. (131 individuals) and Euterpe oleraceae Mart. (87 individuals). Respectively, 17 and 19 species $(8.17 \%$ and $8.6 \%$ of sampled totals) accounted for $50 \%$ of all tree individuals with DBH $>5 \mathrm{~cm}$ sampled in undisturbed and disturbed forests.

Species exclusive to undisturbed forests added up to 49 ( 30 of them rare, that is, with a single individual). Conversely, 62 species were exclusive to disturbed forests, with a higher density of Cochlospermum orinocense (Kunth) Steud.

The upper and middle strata of undisturbed forests had higher values for richness and floristic diversity index than those of disturbed forests. However, considering both strata, undisturbed forests exhibited 2060 individuals, 43 families and 208 species, in contrast to, respectively, 2167, 45 and 221 in disturbed forests (Table 2). Comparing forest types, there is higher species richness and significance

Table 1. List of the 30 most abundant species, with density values (ind/ha) recorded in plots in the upper and middle strata in undisturbed and disturbed forests in Permanet Preservation Areas -PPAs within the municipality of Moju, Pará.

\begin{tabular}{|c|c|c|c|c|}
\hline \multirow[b]{2}{*}{ Species } & \multicolumn{2}{|c|}{ Undisturbed Forest } & \multicolumn{2}{|c|}{ Disturbed Forest } \\
\hline & $\begin{array}{l}\text { Upper } \\
\text { strata }\end{array}$ & $\begin{array}{c}\text { Middle } \\
\text { strata }\end{array}$ & $\begin{array}{l}\text { Upper } \\
\text { strata }\end{array}$ & $\begin{array}{c}\text { Middle } \\
\text { strata }\end{array}$ \\
\hline Eschweilera grandiflora (Aubl.) Sandwith & 40.66 & 19.33 & 48.66 & 31.33 \\
\hline Licania heteromorpha Benth. & 13.00 & 7.33 & 29.33 & 28.66 \\
\hline Euterpe oleracea Mart. & 7.66 & 34.66 & 15.66 & 26.66 \\
\hline Licania sclerophylla (Hook. f.) Fritsch & 17.33 & 25.33 & 12.66 & 21.33 \\
\hline Inga brachyrhachis Harms & 8.66 & 28.66 & 9.00 & 24.00 \\
\hline Zygia cauliflora (Willd.) Killip & 8.66 & 39.33 & 3.66 & 22.00 \\
\hline Cynometra marginata Benth. & 15.66 & 11.33 & 12.00 & 9.33 \\
\hline Hevea brasiliensis (Willd. ex A. Juss.) Müll. Arg. & 15.66 & 0.66 & 15.33 & 4.00 \\
\hline Taralea oppositifolia Aubl. & 16.33 & 2.66 & 11.33 & 2.00 \\
\hline Caraipa grandifolia Mart. & 6.33 & 28.66 & 5.00 & 7.33 \\
\hline Eschweilera coriacea (DC.) S.A. Mori & 10.66 & 6.66 & 13.66 & 2.00 \\
\hline Vatairea guianensis Aubl. & 12.00 & - & 12.66 & 2.66 \\
\hline Eugenia flavescens DC. & - & 14.66 & 6.66 & 20.00 \\
\hline Swartzia acuminata Willd. exVogel & 13.66 & 2.66 & 6.66 & 4.66 \\
\hline Anacardium giganteum W. Hancock ex Engl. & 14.00 & 8.66 & 4.66 & 0.66 \\
\hline Swartzia racemosa Benth. & 7.33 & 8.66 & 5.66 & 11.33 \\
\hline Licania apetala (E. Mey.) Fritsch & 9.33 & 6.00 & 8.00 & 3.33 \\
\hline Gustavia augusta L. & 3.33 & 4.00 & 11.33 & 8.66 \\
\hline Licania macrophylla Benth. & 12.00 & 4.66 & 4.66 & 2.66 \\
\hline Eschweilera apiculata (Miers) A.C. Sm & 7.66 & - & 10.33 & 3.33 \\
\hline Tachigalia myrmecophila (Ducke) Ducke & 6.66 & 4.66 & 5.00 & 10.66 \\
\hline Macrolobium pendulum Willd. ex Vogel & 8.00 & 2.00 & 7.33 & 4.00 \\
\hline Dialium guianense (Aubl.) Sandwith & 5.33 & 5.33 & 7.00 & 4.66 \\
\hline Attalea maripa (Aubl.) Mart. & 6.33 & - & 20.66 & - \\
\hline Eugenia omissa Mc Vaugh & 2.33 & 8.66 & 2.00 & 12.66 \\
\hline Crudia oblonga Benth. & 5.33 & 1.33 & 7.00 & 3.33 \\
\hline Inga splendens Willd. & 5.66 & 3.33 & 6.00 & 2.66 \\
\hline Unonopsis guatterioides R.E. Fr. & 3.66 & 9.33 & 2.33 & 7.33 \\
\hline Inga capitata Desv. & 4.33 & 4.00 & 6.00 & 3.33 \\
\hline Mora paraensis (Ducke) Ducke & 10.66 & 1.33 & 2.33 & - \\
\hline
\end{tabular}


$(\mathrm{t}=2.891 \mathrm{p}<0.05)$ of the diversity index in well-preserved forests than in the upper stratum of disturbed forests; the same relationship was found in the middle stratum $(t=3.577 \mathrm{p}<0.05)$. Pielou index is higher in undisturbed forests.

The similarity indices between the upper strata of undisturbed forests and disturbed forests, and between the middle strata of each type, were the highest found (Table 3); no index was lower than 50\%, suggesting a certain floristic resemblance between forest types.

Considering both undisturbed and disturbed forests, the mean density of individuals in the upper stratum was $468 \mathrm{ind} / \mathrm{ha}$, and the mean basal area, $25.98 \mathrm{~m}^{2} /$ ha. In the middle stratum, the mean density was $470 \mathrm{ind} / \mathrm{ha}$ and the mean basal area, $1.90 \mathrm{~m}^{2} /$ ha (Table 4 ).
Distribution of the number of individuals per diameter class tended to follow a negative exponential function (inverted J), with many small-diameter individuals and few large-diameter ones (Figure 2).Swartzia acuminata Willd.ex Vogel and Taralea oppositifolia Aubl.were the species with the highest number of individuals with diameters above $70 \mathrm{~cm}$ in undisturbed forests; in disturbed forests, the species with the most numerous large-diameter individuals were Eschweilera coriacea (DC.) S.A. Mori and Bertholletia excelsa Bonpl. We observed that in the $\mathrm{DBH} \leq 10 \mathrm{~cm}$ class, the number of individuals per hectare was higher in disturbed (494.67) than in undisturbed forests (451.33); also, the $10 \mathrm{~cm} \leq \mathrm{DBH} \leq 20 \mathrm{~cm}$ class exhibited the widest difference between the two forest types, with 225 individuals per hectare recorded in undisturbed forests and 298.67 individuals/ha in disturbed forests (Figure 2).

Table 2. Floristic information on tree species in undisturbed and disturbed forests within PPAs in the municipality of Moju, Pará.

\begin{tabular}{|c|c|c|c|c|c|c|}
\hline Stratum/Floristics & $\begin{array}{c}\mathbf{N}^{\mathbf{0}} \\
\text { Ind. }\end{array}$ & $\mathbf{H}^{\prime}$ & $\mathbf{J}$ & $\mathbf{N f}$ & $\mathbf{N g}$ & Ns \\
\hline Undisturbed forest & 2060 & & & 43 & & 208 \\
\hline Upper stratum $(D B H \geq 10 \mathrm{~cm})$ & & 3.36 & 0.91 & 40 & 101 & 167 \\
\hline Middle stratum $(9.99 \mathrm{~cm} \geq D B H \geq 5.0 \mathrm{~cm})$ & & 3.06 & 0.92 & 37 & 95 & 134 \\
\hline Disturbedforest & 2167 & & & 45 & & 221 \\
\hline Upperstratum $(\mathrm{DBH} \geq 10 \mathrm{~cm})$ & & 3.05 & 0.85 & 39 & 100 & 164 \\
\hline Middle stratum $(9.99 \mathrm{~cm} \geq D B H \geq 5.0 \mathrm{~cm})$ & & 2.64 & 0.84 & 40 & 110 & 156 \\
\hline
\end{tabular}

$\mathrm{N}^{\mathrm{o}}$ Ind. = number of individuals, $\mathrm{H}^{\prime}=$ Shannon-Wiener Diversity Index, $\mathrm{J}^{\prime}=$ Pielou Equability Index, $\mathrm{Nf}=$ number of families, $\mathrm{Ng}=$ number of genera, $\mathrm{Ns}=$ number of species.

Table 3. Sørensen Similarity Indices for undisturbed and disturbed riparian forests within PPAs in the municipality of Moju, Pará, considering two strata.

\begin{tabular}{lccccc}
\hline \multicolumn{1}{c}{ Stratum/Floristic similarity } & \multicolumn{2}{c}{ Undisturbed forest } & & \multicolumn{2}{c}{ Disturbed forest } \\
\cline { 2 - 3 } \cline { 5 - 6 } & US & MS & & US & MS \\
\hline Undisturbed forest - US & - & 0.51 & & 0.63 & 0.56 \\
Undisturbed forest - MS & & - & 0.54 & 0.66 \\
Disturbed forest - US & & & - & 0.58 \\
Disturbed forest - MS & & & & - \\
\hline
\end{tabular}

US, upper stratum; MS, middle stratum.

Table 4. Mean density (number of individuals/ha), aerial biomass $\left(\mathrm{Mg}^{-h a^{-1}}\right)$ and basal $\operatorname{area}\left(\mathrm{m}^{2} / \mathrm{ha}\right)$ for undisturbed and disturbed forests within PPAs in the municipality of Moju, Pará. $\left(\mathrm{n}=12,2500 \mathrm{~m}^{2}\right.$ for each upper stratum plot; $\mathrm{n}=12,1250 \mathrm{~m}^{2}$ for each middle stratum plot).

\begin{tabular}{lccr}
\hline \multicolumn{1}{c}{ Stratum/Structure } & Density & Biomass & Basal Area \\
\hline Undisturbed forest & & & \\
Upper stratum & 461.00 & $341.90 \pm 83.30$ & $1.02 \pm 9.06$ \\
Middle stratum & 451.33 & $11.65 \pm 2.26$ & $1.89 \pm 0.28$ \\
Total & 912.33 & $353.35 \pm 83.02$ & $32.91 \pm 9.08$ \\
Disturbed forest & & & \\
Upper stratum & 475.00 & $230.50 \pm 23.89$ & $20.95 \pm 3.78$ \\
Middle stratum & 494.67 & $12.48 \pm 4.45$ & $1.92 \pm 0.47$ \\
Total & 969.67 & $242.98 \pm 26.19$ & $22.86 \pm 3.65$ \\
\hline
\end{tabular}




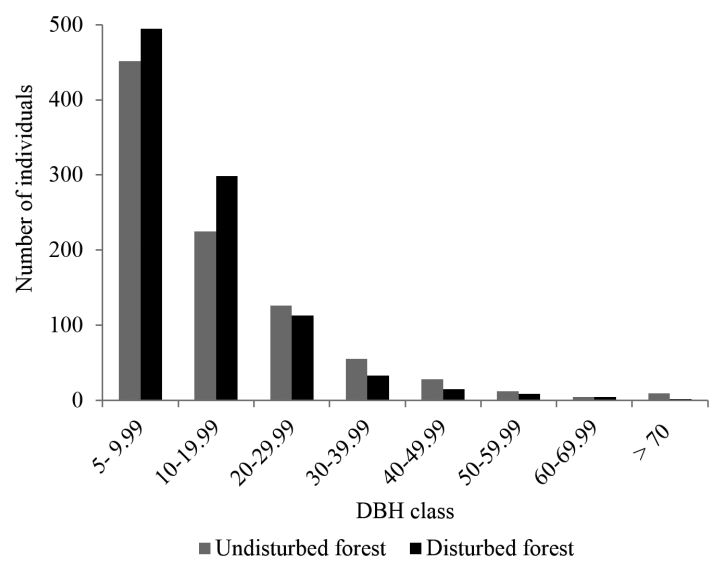

Figure 2. Number of individuals/ha distributed in different DBH classes in disturbed and undisturbed forests within PPAs in the municipality of Moju, Pará.

Those pattern of diameter distribution in both upper and middle strata did not present differences between forest types as showed by Kolmogorov-smirnov test $(\mathrm{Ks} \mathrm{max}=0.250$, $\mathrm{p}=0.906$ ).

Aerial biomass was $353.35 \mathrm{Mg} \cdot \mathrm{ha}^{-1}$ for undisturbed forests and $242.98 \mathrm{Mg} \cdot \mathrm{ha}^{-1}$ for disturbed forests. Vila Braulande had the highest biomass values for both strata (392.20 Mg.ha- ${ }^{-1}$ ), a major contribution for the high value found in undisturbed forests; this locality also had the highest mean biomass value (257.60 Mg.ha $\left.{ }^{-1}\right)$. Differences between forest types were statistically significant $(t=4.263 p<0.05)$ (Figure 3; Table 3). The mean basal area of the upper stratum of disturbed forests was smaller $\left(20.95 \mathrm{~m}^{2} / \mathrm{ha}\right)$ than the value found for undisturbed forests $\left(31.02 \mathrm{~m}^{2} / \mathrm{ha}\right)$.

The first and second axes of the NMDS in disturbed and undisturbed forest plots (stress value $=0.15$ and 0.21 for upper and middle strata) did not group the forests by their floristic composition (Figure 4). This result was confirmed by ANOSIM analysis ( $\mathrm{R}=0.026, \mathrm{p}=0,27,999$ permutations) which suggest that the disturbance observed in the forest plots is not interfering in species composition of tree communities studied for trees with $\mathrm{dbh} \geq 10 \mathrm{~cm}$ and for individuals between 5 and $10 \mathrm{~cm} \mathrm{DBH}$.

However we observed the formation of two groups in the middle stratum of both disturbed and undisturbed plots (Figure $4 \mathrm{~b}$ ). The first group was formed by the localities of Vila Olho D'água, Vila São Tomé and Vila Braulande; the second by Vila Soledade, Vila São Jorge and Vila São Pedro. The distribution of species richness, abundance and basal area for each forest type of these rural villages were showed in Figure 5.

\section{Discussion}

The results in the present study revealed that the species richness and abundance of Permanent Preservation Areas forests of Moju river were comparable to other terra firme forests of eastern Amazonia (Salomão et al., 1988;
Two-sample t-test

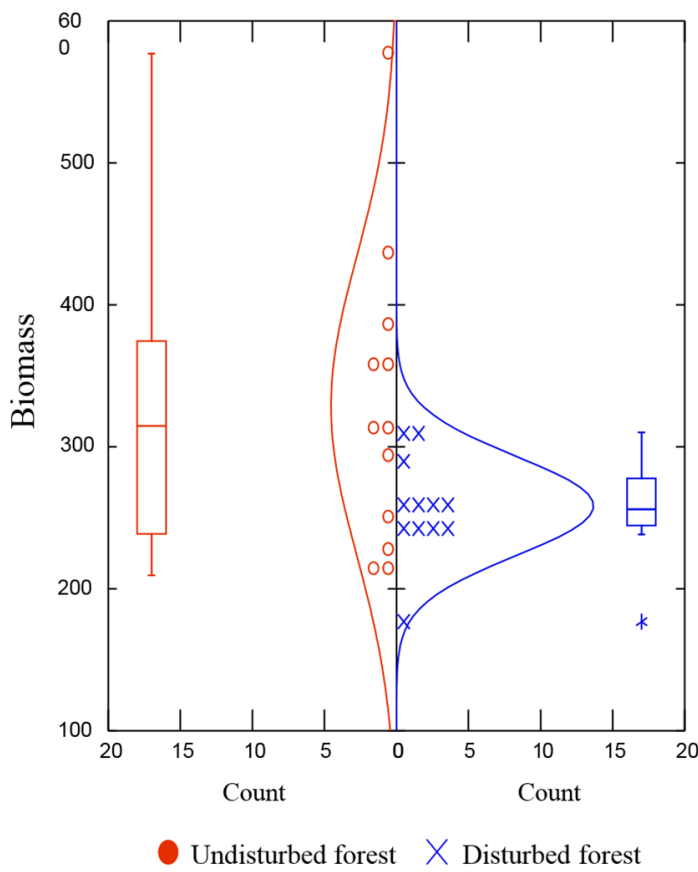

Figure 3. Student's t-test for mean biomass in undisturbed and disturbed forests within PPAs in the municipality of Moju, Pará.

Amaral et al., 2012). The most of the individual stems belong to a relatively small number of species and many of these species are hyperdominants (Ter Steege et al., 2013). Also the floristic richness observed in the upper and middle strata in the PPAs surveyed (208 species in undisturbed forests, 221 in disturbed ones) was considered high in comparison with other PPAs areas studied in the same region (Pinheiro et al., 2007), where 158 were sampled.

This study found higher species richness in disturbed than undisturbed forests (Table 3). Of the 270 species sampled in the two forest types of Moju, only 96 (36\%) were common to both, 62 exclusive to disturbed forests in PPAs and 49 found only in undisturbed forests. The cause of such high richness should be attributed to the higher environmental heterogeneity resulting from disturbances in the uniform structure of the forest. In the case of the forests of Moju, it should be noted that, from the 270 species sampled, only 19 accounted for about $50 \%$ of the total number of individuals found: those are hyperdominant species, as defined by Ter Steege et al. (2013). In the forests near Moju, Rodrigues et al. (1997) found about $51 \%$ of individuals belonging to only nine species, a situation frequent in throughout the Amazonian forest region.

The family Fabaceae predominate in terms of species richness in both undisturbed and disturbed forests. It is highly frequent in the Neotropics (Ribeiro et al., 1999), and its richness in vegetation formations in Amazonia is mentioned by many authors who verified its wide geographic 

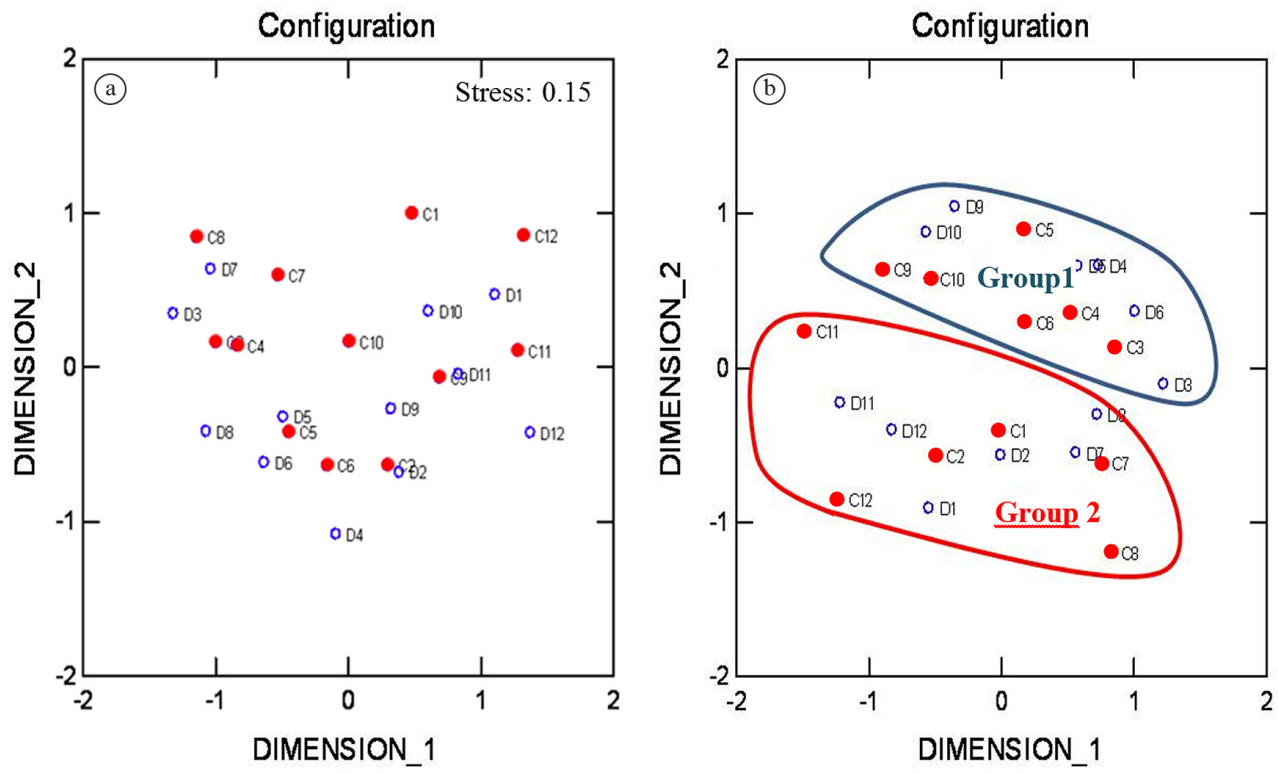

Figure 4. MDS analysis performed for tree species composition in the upper (a) and middle (b) strata for 24 plots of undisturbed and disturbed forests within PPAs, where: $\mathrm{C}=$ undisturbed forests; $\mathrm{D}=$ disturbed forests; 1 and $2=$ Vila Olho D'água; 3 and 4 = Vila Soledade; 5 and 6 =Vila São Jorge; 7 and 8 = Vila São Tomé; 9 and $10=$ Vila São Pedro; 11 and 12 = Vila Braulande.
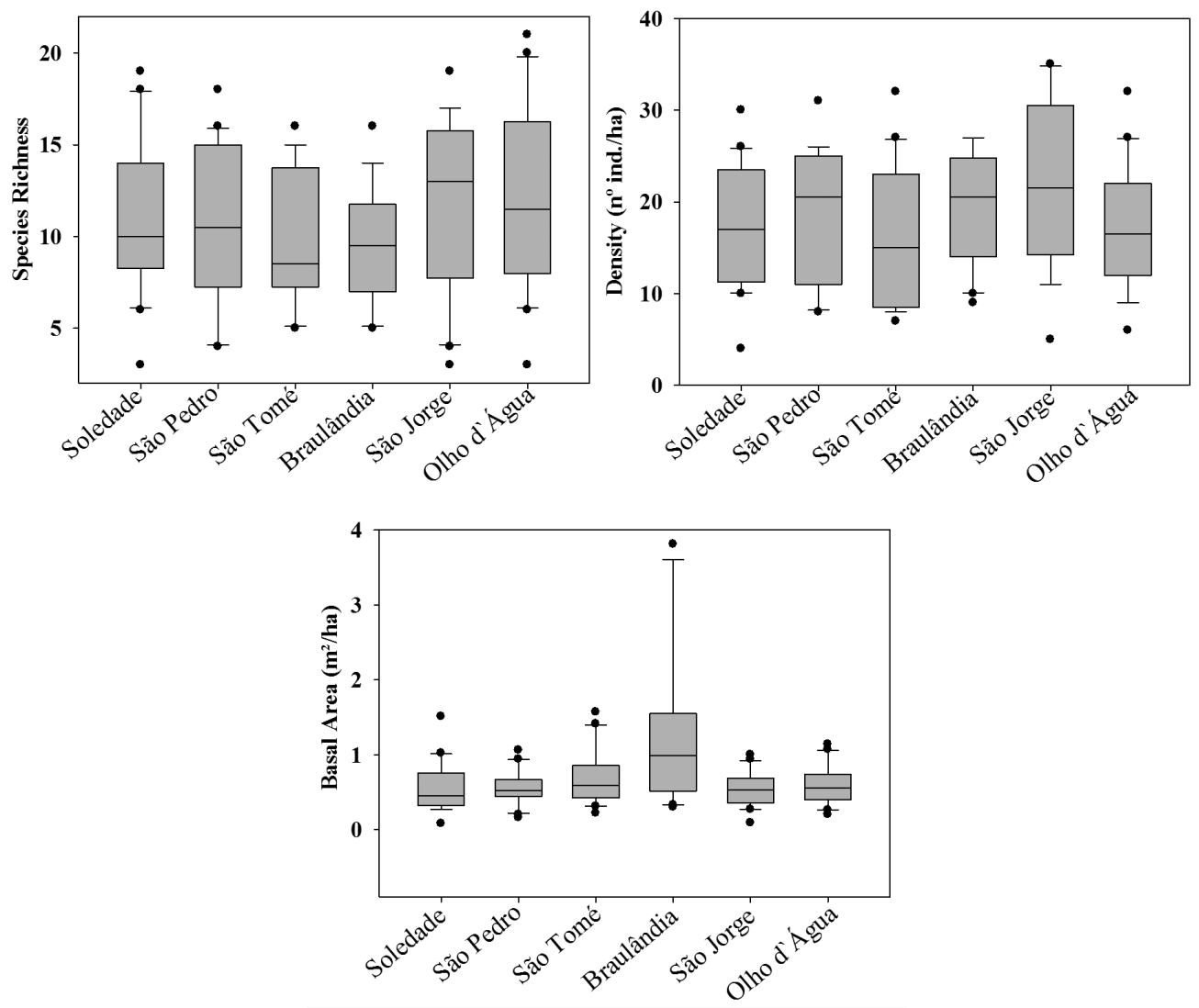

Figure 5. Box-plot showing the distribution of richness, density and basal area of disturbed and undisturbed forests in PPAs of six rural communities studied in Moju, Pará. 
distribution and high ecological plasticity (Pires, 1973). In areas dominated by upland forests in Amazonia, the families Sapotaceae, Moraceae and Burseraceae are also referred to as the most species-rich in other floristic inventories in the region (Pires, 1973; Prance et al., 1976; Dantas et al., 1980; Amaral et al., 2012). Other families found in the present study were Chrysobalanaceae and Lecythidaceae, which in Amazonia exhibit the highest densities of individuals and species, along with the Fabaceae (Oliveira and Amaral, 2004).

Overall, the disturbed forests surveyed had lower basal area values $\left(20.95 \mathrm{~m}^{2}\right)$ than those recorded for upland forests in Amazonia, which are of about 30-40 $\mathrm{m}^{2}$ (Salomão et al., 1988; Pitman et al., 2001). The aboveground biomass was higher in undisturbed forests than in disturbed ones, which had undergone selective logging common practice in the Moju river basin. Vila Braulande had the highest biomass value (392.20 Mg.ha-1), evidencing its high degree of protection in comparison to other undisturbed forests, and especially to those classified as disturbed. That community collects only non-wood forest resources, such as oils and resins, which could have had an effect on this level of protection. In general, the response of the forests to disturbance is different in each rural communities (Figure 5). The mosaic of preserved and degraded forests present in an anthropogenic landscape such as these of Moju is the result of both the rural land use dynamics and the Forest Code, by requiring that $80-50 \%$ of the properties must be maintained as legal reserves (reserva legal) does not provide guidance as to its conservation status and format.

This study suggests that the impacts caused by humans on the Moju river communities did not lead to great floristic changes. Also, there were no significant differences between the analysed strata with respect to floristics (richness, Shannon-Wiener diversity, density). However, man-made impacts were perceptible in the tree community structure. As for the floristic composition, multivariate analysis evidenced there are no clear differences between forests respectively considered undisturbed and disturbed, which could be due to the different stages of preservation in PPAs or to their low level of exploitation by local communities - which have not seriously impacted the forest under their domain.

\section{Conclusions}

Floristic data on richness, abundance and tree species composition did not show any association with the conservation status of the PPAs, indicating that even the disturbed PPAs support viable populations of many tree species, therefore they should be maintained within rural properties. Moreover, the disturbance of forests within the PPAs seems to have been slight, not having significantly jeopardized the community of tree plants with respect to floristics. This favors the use of the most abundant species in the recovery of disturbed PPAs. The impact in the structure of the tree assembly was perceptible in such a way that disturbed forests exhibited a smaller basal area and biomass.

\section{Acknowledgements}

This paper forms part of a thesis prepared for the Master's graduate program in Biological Sciences at Museu Paraense Emilio Goeldi in conjunction with the Universidade Federal Rural da Amazônia. We are grateful to the Instituto Nacional de Ciência e Tecnologia, Biodiversidade e Uso da Terra na Amazônia (CNPq grant 574008/2008-0), for financial supportand to CNPq for an MScs cholarship to JCO and a productivity grant (CNPq 306368/2013-7) to ICGV.

\section{References}

ALMEIDA, A.S. and VIEIRA, I.C.G., 2014. Conflitos no uso da terra em áreas de preservação permanente em um polo de produção de biodisel no Estado do Pará. Revista Ambiente \& Água, vol. 9, pp. 476-487.

ALMEIDA, A.S. and VIEIRA, I.G.V., 2010. Centro de Endemismo Belém: status da vegetação remanescente e desafios para a conservação da biodiversidade e restauração ecológica. Revista de Estudos Universitários, vol. 36, no. 3, pp. 95-111.

AMARAL, D.D., VIEIRA, I.C.G., SALOMÃO, R.P., ALMEIDA, S.S. and JARDIM, M.A.G., 2012. The status of conservation of urban forests in eastern Amazonia. Brazilian Journal of Biology $=$ Revista Brasileira de Biologia, vol. 72, no. 2, pp. 257-265. http:// dx.doi.org/10.1590/S1519-69842012000200005.PMid:22735132.

BRASIL. Conselho Nacional do Meio Ambiente - CONAMA, 2002. [viewed 27 March 2013]. Resolução CONAMA nº 302, de 20 de março de 2002. Dispõe sobre os parâmetros, definições e limites de Áreas de Preservação Permanente de reservatórios artificiais e o regime de uso do entorno. Diário Oficial da República Federativa do Brasil [online], Brasília, 13 maio. Available from: http://www.jurisambiente.com.br/ambiente/areadepreservacaol.shtm.

CLARKE, K.R. and GORLEY, R.N., 2006. PRIMER v6: user manual/tutorial. Plymouth: PRIMER-E. 192 p.

CONSULTORIA E DESENVOLVIMENTO DE SISTEMAS CIENTEC, 2002. Mata nativa: sistema para análise fitossociológica e elaboração de planos de manejo de florestas nativas. São Paulo: CIENTEC. 126 p.

COSTA, D.H.M., FERREIRA, C. A. P., SILVA, J. N. M., LOPES, J. C. A. and CARVALHO, J. O. P., 1998. Potencial madeireiro de floresta densa no município de Moju, Estado do Pará. Belém: Embrapa-CPATU. 33 p. Documentos, no. 121.

DANTAS, M., RODRIGUES, I.M.A. and MULLER, N.R.M., 1980. Estudos fito-ecológicos do trópico úmido brasileiro: aspectos fitossociológicos de mata sobre latossolo amarelo em Capitão Poço. Boletim de Pesquisa e Desenvolvimento EMBRAPA, vol. 9, pp. 23-38.

HASTON, E., RICHARDSON, J.E., STEVENS, P.F., CHASE, M.W. and HARRIS, D.J., 2009. The Linear Angiosperm Phylogeny Group (LAPG) III: A linear sequence of the families in APG III. Botanical Journal of the Linnean Society, vol. 161, no. 2, pp. 128-131. http://dx.doi.org/10.1111/j.1095-8339.2009.01000.x.

HIGUCHI, N., SANTOS, J., RIBEIRO, R.J., MINETTE, L. and BIOT, Y., 1998. Biomassa da parte aérea da vegetação da floresta tropical úmida de terra-firme da Amazônia Brasileira. Acta Amazônica, vol. 28, no. 2, pp. 153-166. http://dx.doi. org/10.1590/1809-43921998282166. 
MAGURRAN, A.E., 2004. Measuring biological diversity. Oxford: Blackwell Science. 256 p.

MUELLER-DUMBOIS, D. and ELLENBER, H., 1974. Aims and methods of vegetation ecology. New York: John Willey \& Sons Press. 574 p.

NASCIMENTO, C. and HOMMA, A., 1984. Amazônia: meio ambiente e tecnologia agrícola. Belém: Embrapa-CPATU. 282 p. Documentos, no. 27.

NEPSTAD, D.C., VERÍSSIMO, J.A., ALENCAR, A., NOBRE, C., LIMA, E., LEFEBVRE, P., SCHLESINGER, P., POTTER, C., MOUTINHO, P., MENDOZA, E., COCHRANE, M. and BROOKS, V., 1999. Large-scale impoverishment of Amazonian forests by logging and fire. Nature, vol. 398, no. 6727, pp. 504508. http://dx.doi.org/10.1038/19066.

OLIVEIRA, A.N. and AMARAL, I.L., 2004. Florística e fitossociologia de uma floresta de vertente na Amazônia Central, Amazonas, Brasil. Acta Amazonica, vol. 34, no. 1, pp. 21-34. http://dx.doi.org/10.1590/S0044-59672004000100004

PINHEIRO, K.A.O., CARVALHO, J.O.P., QUANZ, B., FRANCEZ, L.M.B. and SCHWARTZ, G., 2007. Fitossociologia de uma área de preservação permanente no leste na Amazônia: indicação de espécies para recuperação de áreas alteradas. Revista Floresta, vol. 37, pp. 175-187.

PIRES, J.M., 1973. Tipos de vegetação da Amazônia. Boletim do Museu Paraense Emílio Goeldi, vol. 20, pp. 179-202.

PITMAN, N.C.A., TERBORGH, J.W., SILMAN, M.R., NÚÑEZ, P.V., NEILL, D.A., CERÓN, C.E., PALACIOS, W.A. and AULESTIA, M., 2001. Dominance and distribution of tree species in upper amazonian terra firme forests. Ecology, vol. 82, no. 8, pp. 21012117. http://dx.doi.org/10.1890/0012-9658(2001)082[2101:DA DOTS]2.0.CO;2.

PRANCE, G.T., RODRIGUES, W.A. and SILVA, M.F., 1976. Inventário florestal de um hectare de Mata de Terra Firme, Km 30 estrada Manaus-Itacoatiara. Acta Amazonica, vol. 6, no. 1, pp. 9-35.

RIBEIRO, J.E.L.S., HOPKINS, M.J.G., VICENTINI, A., SOTHERS, C.A., COSTA, M.A.S., BRITO, J.M., SOUZA, M.A.D., MARTINS, L.H.P., LOHMANN, L.G., ASSUNÇÃO, P.A.C.L., PEREIRA, E.C., SILVA, C.F., MESQUITA, M.R. and PROCÓPIO, L.C., 1999. Flora da Reserva Ducke: guia de identificação das plantas vasculares de uma floresta de terra-firme na Amazônia Central. Manaus: Instituto Nacional de Pesquisas da Amazônia. 799 p.

RODRIGUES, I.A., PIRES, J.M., WATRIN, O.S. and CORDEIRO, M.R., 1997. Levantamento fitossociológico em áreas sob influência da rodovia PA 150 nos municípios de Acará e Tailândia, PA. Belém: Embrapa Amazônia Oriental. 43 p. Boletim de Pesquisa, no. 179.

SALOMÃO, R.P., SILVA, M.F.F. and ROSA, P.L.B., 1988. Inventário ecológico em Floresta Pluvial Tropical de Terra Firme, Serra Norte, Carajás, Pará. Boletim do Museu Paraense Emílio Goeldi, vol. 4, no. 1, pp. 1-46.
SANTOS, P.L., SILVA, J.M.L., SILVA, B.N.R., SANTOS, R.D. and REGO, G.S., 1985. Levantamento semi detalhado dos solos e avaliação da aptidão agrícola das terras para culturas de dendê e seringueira. Rio de Janeiro: EMBRAPA/SNLCS. 192 p. Projeto Moju, Pará. Relatório técnico.

SERRÃO, D.R., JARDIM, F.C.S. and NEMER, T.C., 2003. Sobrevivência de seis espécies florestais em uma área explorada seletivamente no município de Moju, Pará. Cerne, vol. 9, no. 2, pp. 153-163.

SOKAL, R. and ROHLF, F.J., 1995. Biometry: the principles and practice of statistics in biological research. 3rd ed. New York: W. H. Freeman. 887 p.

SPAROVEK, G.; BARRETO, A.; KLUG, I.; PAPP, L. and LINO, J., 2011. A revisão do Código Florestal brasileiro. Novos Estudos - CEBRAP, no. 89, pp.111-135. http://dx.doi.org/10.1590/S010133002011000100007

TER STEEGE, H., PITMAN, N.C.A., SABATIER, D., BARALOTO, C., SALOMAO, R.P., GUEVARA, J.E., PHILLIPS, O.L., CASTILHO, C.V., MAGNUSSON, W.E., MOLINO, J.-F., MONTEAGUDO, A., NUNEZ VARGAS, P., MONTERO, J.C., FELDPAUSCH, T.R., CORONADO, E.N.H., KILLEEN, T.J., MOSTACEDO, B., VASQUEZ, R., ASSIS, R.L., TERBORGH, J., WITTMANN, F., ANDRADE, A., LAURANCE, W.F., LAURANCE, S.G.W., MARIMON, B.S., MARIMON, B.-H., GUIMARAES VIEIRA, I.C., AMARAL, I.L., BRIENEN, R., CASTELLANOS, H., CARDENAS LOPEZ, D., DUIVENVOORDEN, J.F., MOGOLLON, H.F., MATOS, F.D.A., DAVILA, N., GARCIAVILLACORTA, R., STEVENSON DIAZ, P.R., COSTA, F., EMILIO, T., LEVIS, C., SCHIETTI, J., SOUZA, P., ALONSO, A., DALLMEIER, F., MONTOYA, A.J.D., FERNANDEZ PIEDADE, M.T., ARAUJO-MURAKAMI, A., ARROYO, L., GRIBEL, R., FINE, P.V.A., PERES, C.A., TOLEDO, M., AYMARD C, G.A., BAKER, T.R., CERON, C., ENGEL, J., HENKEL, T.W., MAAS, P., PETRONELLI, P., STROPP, J., ZARTMAN, C.E., DALY, D., NEILL, D., SILVEIRA, M., PAREDES, M.R., CHAVE, J., LIMA FILHO, D.A., JORGENSEN, P.M., FUENTES, A., SCHONGART, J., CORNEJO VALVERDE, F., DI FIORE, A., JIMENEZ, E.M., PENUELA MORA, M.C., PHILLIPS, J.F., RIVAS, G., VAN ANDEL, T.R., VON HILDEBRAND, P., HOFFMAN, B., ZENT, E.L., MALHI, Y., PRIETO, A., RUDAS, A., RUSCHELL, A.R., SILVA, N., VOS, V., ZENT, S., OLIVEIRA, A.A., SCHUTZ, A.C., GONZALES, T., TRINDADE NASCIMENTO, M., RAMIREZ-ANGULO, H., SIERRA, R., TIRADO, M., UMANA MEDINA, M.N., VAN DER HEIJDEN, G., VELA, C.I.A., VILANOVA TORRE, E., VRIESENDORP, C., WANG, O., YOUNG, K.R., BAIDER, C., BALSLEV, H., FERREIRA, C., MESONES, I., TORRES-LEZAMA, A., URREGO GIRALDO, L.E., ZAGT, R., ALEXIADES, M.N., HERNANDEZ, L., HUAMANTUPA-CHUQUIMACO, I., MILLIKEN, W., PALACIOS CUENCA, W., PAULETTO, D., VALDERRAMA SANDOVAL, E., VALENZUELA GAMARRA, L., DEXTER, K.G., FEELEY, K., LOPEZ-GONZALEZ, G. and SILMAN, M.R., 2013. Hyperdominance in the Amazonian tree flora. Science, vol. 342, no. 6156, pp. 1243092. http://dx.doi. org/10.1126/science.1243092. PMid:24136971. 
Appendix 1. List of families/species (and their abundance values) recorded in plots in the upper $\left(\mathrm{N}=12,2500 \mathrm{~m}^{2} ; 3\right.$ ha sampled) and middle strata $\left(\mathrm{N}=60,250 \mathrm{~m}^{2} ; 1.5\right.$ ha sampled) in both undisturbed and disturbed forests in Permanent Preservation Areas -PPAs within the municipality of Moju, Pará, Brazil.

\begin{tabular}{|c|c|c|}
\hline \multirow{2}{*}{ Family/Specie } & \multicolumn{2}{|c|}{ Number of individuals sampled } \\
\hline & Undisturbed forests & Disturbed forests \\
\hline \multicolumn{3}{|l|}{ ANACARDIACEAE } \\
\hline Anacardium giganteum W. Hancock ex Engl. & 55 & 15 \\
\hline Spondias mombin L. & - & 1 \\
\hline Tapirira guianensis Aubl. & 15 & 15 \\
\hline \multicolumn{3}{|l|}{ ANNONACEAE } \\
\hline Annona densicoma Mart. & 2 & 1 \\
\hline Duguetia echinophora R.E. Fr. & - & 4 \\
\hline Duguetia quitarensis Benth. & 3 & - \\
\hline Duguetia riparia Huber & 1 & - \\
\hline Duguetia sandwithii R.E. Fr. & - & 2 \\
\hline Duguetia spixiana Mart. & 2 & - \\
\hline Guatteria poeppigiana Mart. & - & 3 \\
\hline Guatteria schomburgkiana Mart. & - & 5 \\
\hline Unonopsis guatterioides R.E. Fr. & 25 & 18 \\
\hline Xylopia amazonica R.E. Fr. & - & 2 \\
\hline Xylopia benthamii R.E. Fr. & - & 2 \\
\hline Xylopia cayennensis Maas & - & 1 \\
\hline Xylopia nitida Dunal & 3 & 3 \\
\hline \multicolumn{3}{|l|}{ APOCYNACEAE } \\
\hline Ambelania acida Aubl. & 4 & - \\
\hline Aspidosperma excelsa Marcondes-Ferreira & - & 1 \\
\hline Aspidosperma nítida Woodson & - & 1 \\
\hline Himatanthus sucuuba (Spruce ex Müll. Arg.) Woodson & - & 2 \\
\hline Malouetia lata Markgr. & - & 1 \\
\hline \multicolumn{3}{|l|}{ ARALIACEAE } \\
\hline Schefflera morototoni (Aubl.) Maguire, Steyerm. \& Frodin & 5 & 5 \\
\hline \multicolumn{3}{|l|}{ ARECACEAE } \\
\hline Astrocaryum gynacanthum Mart. & 6 & - \\
\hline Astrocaryum jauari Mart. & 2 & 2 \\
\hline Astrocaryum murumuru Mart. & 1 & 1 \\
\hline Astrocaryum vulgare Mart. & - & 10 \\
\hline Attalea maripa (Aubl.) Mart. & 19 & 31 \\
\hline Bactris maraja Mart. & 1 & 7 \\
\hline Euterpe oleracea Mart. & 75 & 87 \\
\hline Mauritia flexuosa L. f. & & 1 \\
\hline Oenocarpus bacaba Mart. & 9 & 4 \\
\hline Syagrus cocoides Mart. & 2 & 3 \\
\hline \multicolumn{3}{|l|}{ BIGNONIACEAE } \\
\hline Jacaranda copaia (Aubl.) D.Don & 14 & 20 \\
\hline \multicolumn{3}{|l|}{ BIXACEAE } \\
\hline Cochlospermum orinocense (Kunth) Steud. & - & 11 \\
\hline \multicolumn{3}{|l|}{ BORAGINACEAE } \\
\hline Cordia exaltata Lam. & 7 & 11 \\
\hline Cordia scabrida Mart. & 1 & - \\
\hline Cordia tetrandra Aubl. & 1 & - \\
\hline
\end{tabular}


Appendix 1. Continued...

\begin{tabular}{|c|c|c|}
\hline \multirow{2}{*}{ Family/Specie } & \multicolumn{2}{|c|}{ Number of individuals sampled } \\
\hline & Undisturbed forests & Disturbed forests \\
\hline \multicolumn{3}{|l|}{ BURSERACEAE } \\
\hline Protium apiculatum Swart & - & 3 \\
\hline Protium heptaphyllum (Aubl.) Marchand & 20 & 10 \\
\hline Protium krukoffii Swart & 1 & - \\
\hline Protium pilosum (Cuatrec.) D.C. Daly & - & 2 \\
\hline Protium trifoliolatum Engl. & 1 & 3 \\
\hline Tetragastris altissima (Aubl.) Swart & 4 & - \\
\hline Trattinnickia burserifolia Mart. & & 2 \\
\hline Trattinnickia rhoifolia Willd. & 1 & 1 \\
\hline \multicolumn{3}{|l|}{ CALOPHYLLACEAE } \\
\hline Calophyllum brasiliense Cambess. & 1 & 1 \\
\hline Caraipa grandifolia Mart. & 62 & 26 \\
\hline Caraipa richardiana Cambess. & 3 & 6 \\
\hline \multicolumn{3}{|l|}{ CELASTRACEAE } \\
\hline Maytenus myrsinoides Reissek & 6 & 4 \\
\hline \multicolumn{3}{|l|}{ CHRYSOBALANACEAE } \\
\hline Hirtella eriandra Benth. & 26 & 5 \\
\hline Licania apetala (E. Mey.) Fritsch & 37 & 29 \\
\hline Licania canescens Benoist & 1 & 1 \\
\hline Licania guianensis Klotzsch & 2 & - \\
\hline Licania heteromorpha Benth. & 50 & 131 \\
\hline Licania licaniiflora (Sagot) S.F. Blake & 3 & 3 \\
\hline Licania macrophylla Benth. & 43 & 18 \\
\hline Licania membranacea Sagot ex Laness. & 16 & 25 \\
\hline Licania oblongifolia Standl. & 1 & - \\
\hline Licania parviflora Benth. & 2 & - \\
\hline Licania sclerophylla (Hook. f.) Fritsch & 90 & 70 \\
\hline Parinari montana Aubl. & 1 & 1 \\
\hline \multicolumn{3}{|l|}{ CLUSIACEAE } \\
\hline Rheedia brasiliensis (Mart.) Planch. \& Triana & 15 & 2 \\
\hline Rheedia macrophylla (Mart.) Planch. \& Triana & 10 & 14 \\
\hline Tovomita brasiliensis (Mart.) Walp. & 1 & 1 \\
\hline Tovomita brevistaminea Engl. & 1 & - \\
\hline \multicolumn{3}{|l|}{ COMBRETACEAE } \\
\hline Buchenavia ochroprumna Eichler & 3 & 1 \\
\hline Buchenavia oxycarpa (Mart.) Eichler & & 1 \\
\hline Terminalia argentea Mart. & 1 & - \\
\hline Terminalia dichotoma $\mathrm{G}$. Mey. & 2 & 2 \\
\hline \multicolumn{3}{|l|}{ EBENACEAE } \\
\hline Diospyros artanthifolia Mart. & 14 & 19 \\
\hline Diospyros guianensis (Aubl.) Gürke & 2 & - \\
\hline \multicolumn{3}{|l|}{ ELAEOCARPACEAE } \\
\hline Sloanea guianensis (Aubl.) Benth. & 3 & - \\
\hline \multicolumn{3}{|l|}{ EUPHORBIACEAE } \\
\hline Conceveiba guianensis Aubl. & 2 & 1 \\
\hline Hevea brasiliensis (Willd. ex A. Juss.) Müll. Arg. & 48 & 52 \\
\hline Mabea caudata Pax \& K. Hoffm. & 10 & 6 \\
\hline Pogonophora schomburgkiana Miers ex Benth. & 1 & 1 \\
\hline Sagotia racemosa Baill. & - & 2 \\
\hline
\end{tabular}


Appendix 1. Continued...

\begin{tabular}{|c|c|c|}
\hline \multirow{2}{*}{ Family/Specie } & \multicolumn{2}{|c|}{ Number of individuals sampled } \\
\hline & Undisturbed forests & Disturbed forests \\
\hline \multicolumn{3}{|l|}{ FABACEAE } \\
\hline Abarema jupunba (Willd.) Britton \& Killip & 5 & 5 \\
\hline Acosmium nitens (Vogel) Yakovlev & 6 & 4 \\
\hline Alexa grandiflora Ducke & 1 & - \\
\hline Campsiandra laurifolia Benth. & 2 & 27 \\
\hline Crudia oblonga Benth. & 18 & 26 \\
\hline Cynometra marginata Benth. & 64 & 50 \\
\hline Dialium guianense (Aubl.) Sandwith & 24 & 28 \\
\hline Diplotropis martiusii Benth. & - & 1 \\
\hline Diplotropis purpurea (Rich.) Amshoff & 1 & - \\
\hline Dipteryx odorata (Aubl.) Willd. & & 2 \\
\hline Eperua bijuga Mart. ex Benth. & 15 & 10 \\
\hline Hydrochorea corymbosa (Rich.) Barneby \& J.W. Grimes & 17 & 9 \\
\hline Hymenaea oblongifolia Huber & 9 & 13 \\
\hline Hymenaea parvifolia Huber & 1 & - \\
\hline Hymenaea reticulata Ducke & 2 & 1 \\
\hline Inga alba (Sw) Willd. & 3 & 4 \\
\hline Inga brachyrhachis Harms & 69 & 63 \\
\hline Inga capitata Desv. & 19 & 23 \\
\hline Inga disticha Benth. & 2 & 3 \\
\hline Inga edulis Mart. & 5 & 6 \\
\hline Inga grandiflora Wall. & 1 & 5 \\
\hline Inga laurina (Sw.) Willd. & 8 & 12 \\
\hline Inga macrophylla Humb. \& Bonpl. ex Willd. & 1 & 3 \\
\hline Inga marginata Willd. & 12 & 9 \\
\hline Inga paraensis Ducke & 1 & 6 \\
\hline Inga splendens Willd. & 22 & 22 \\
\hline Inga thibaudiana DC. & 4 & 5 \\
\hline Inga umbellifera (Vahl) Steud. & - & 1 \\
\hline Macrolobium acaciifolium (Benth.) Benth. & 1 & 5 \\
\hline Macrolobium angustifolium (Benth.) R.S. Cowan & 8 & 1 \\
\hline Macrolobium pendulum Willd. ex Vogel & 27 & 28 \\
\hline Mora paraensis (Ducke) Ducke & 34 & 7 \\
\hline Ormosia coutinhoi Ducke & 2 & 4 \\
\hline Parkia discolor Spruce ex Benth. & 4 & 1 \\
\hline Parkia nitida Miq. & 2 & 4 \\
\hline Peltogyne venosa (Vahl) Benth. & 2 & 1 \\
\hline Pentaclethra macrophylla Benth. & 11 & 2 \\
\hline Poecilanthe effusa (Huber) Ducke & 1 & - \\
\hline Platymiscium filipes Benth. & - & 2 \\
\hline Pseudopiptadenia suaveolens (Miq.) J.W. Grimes & 3 & 1 \\
\hline Pterocarpus officinalis Jacq. & 1 & 2 \\
\hline Stryphnodendron guianense (Aubl.) Benth. & 1 & 1 \\
\hline Stryphnodendron paniculatum Poepp. & - & 1 \\
\hline Stryphnodendron pulcherrimum (Willd.) Hochr. & 1 & 3 \\
\hline Swartzia acuminata Willd. ex Vogel & 45 & 27 \\
\hline Swartzia arborescens (Aubl.) Pittier & 1 & 1 \\
\hline Swartzia laurifolia Benth. & - & 1 \\
\hline Swartzia racemosa Benth. & 35 & 34 \\
\hline
\end{tabular}


Appendix 1. Continued...

\section{Family/Specie}

Tachigali goeldiana (Huber) L.F. Gomes da Silva \& H.C. Lima

Tachigalia myrmecophila (Ducke) Ducke

Tachigalia paniculata Aubl.

Taralea oppositifolia Aubl.

Vatairea guianensis Aubl.

Vouacapoua americana Aubl.

Zygia ampla (Spruce ex Benth.) Pittier

Zygia cataractae (Kunth) L. Rico

Zygia cauliflora (Willd.) Killip

GOUPIACEAE

Goupia glabra Aubl.

HUMIRIACEAE

Sacoglottis guianensis Benth.

\section{HYPERICACEAE}

Vismia cayennensis (Jacq.) Pers.

Vismia guianensis (Aubl.) Pers.

\section{LAURACEAE}

Aniba guianensis Aubl.

Licaria rigida (Kosterm.) Kosterm.

Ocotea caudata (Nees) Mez

Ocotea glomerata (Nees) Mez

Ocotea longifolia Kunth

Ocotea rubra Mez

\section{LECYTHIDACEAE}

Allantoma lineata (Mart.\& O.Berg) Miers

Bertholletia excelsa Bonpl.

Couratari guianensis Aubl.

Eschweilera amazonica R. Knuth

Eschweilera apiculata (Miers) A.C. Sm.

Eschweilera coriacea (DC.) S.A. Mori

Eschweilera grandiflora (Aubl.) Sandwith

Eschweilera pedicellata (Rich.) S.A. Mori

Gustavia augusta L.

Lecythis idatimon Aubl.

Lecythis lurida (Miers) S.A. Mori

Lecythis pisonis Cambess.

LINACEAE

Roucheria punctata (Ducke) Ducke

MALPIGHIACEAE

Byrsonima densa (Poir.) DC.

MALVACEAE

Apeiba burchellii Sprague

Apeiba echinata Gaertn.

Eriotheca globosa (Aubl.) A. Robyns

Eriotheca longipedicellata (Ducke) A. Robyns

Pseudobombax munguba (Mart. \& Zucc.) Dugand

Sterculia pruriens (Aubl.) K.Schum.

Sterculia speciosa K. Schum.

Theobroma speciosum Willd. ex Spreng.

Theobroma subincanum Mart.

Number of individuals sampled

Undisturbed forests Disturbed forests

2

27

1

53

36

22

$-$

1

85

2

-

1

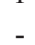

7

8

2

1

- 1

- 1

78

- 4

12

- 2

$23 \quad 36$

$42 \quad 44$

$151 \quad 193$

$\begin{array}{ll}7 & 4\end{array}$

$16 \quad 47$

1

1 -

23

4

1

$\begin{array}{ll}3 & 1 \\ 4 & - \\ 1 & 2 \\ 1 & 2 \\ 4 & - \\ 11 & 3 \\ - & 1 \\ - & 4 \\ 2 & 1\end{array}$


Appendix 1. Continued...

\begin{tabular}{|c|c|c|}
\hline \multirow{2}{*}{ Family/Specie } & \multicolumn{2}{|c|}{ Number of individuals sampled } \\
\hline & Undisturbed forests & Disturbed forests \\
\hline \multicolumn{3}{|l|}{ MELASTOMATACEAE } \\
\hline Bellucia grossularioides (L.) Triana & 1 & 1 \\
\hline Henriettea succosa (Aubl.) DC. & 1 & 1 \\
\hline Miconia affinis DC. & 1 & 11 \\
\hline Miconia gratissima Benth. ex Triana & - & 2 \\
\hline Miconia pyrifolia Naudin & - & 2 \\
\hline Miconia tomentosa (Rich.) D. Don ex DC. & 1 & 7 \\
\hline Mouriri acutiflora Naudin & 13 & 1 \\
\hline Mouriri apiranga Spruce ex Triana & 5 & 3 \\
\hline Mouriri brachyanthera Ducke & 4 & 12 \\
\hline Mouriri grandiflora DC. & 4 & - \\
\hline Mouriri nervosa Pilg. & - & 1 \\
\hline Mouriri nigra (DC.) Morley & 3 & 3 \\
\hline \multicolumn{3}{|l|}{ MELIACEAE } \\
\hline Carapa grandiflora Sprague & 1 & - \\
\hline Carapa guianensis Aubl. & 19 & 19 \\
\hline Cedrela odorata Vell. & - & 2 \\
\hline Guarea guidonia (L.) Sleumer & 2 & 6 \\
\hline Trichilia micrantha Benth. & 11 & 24 \\
\hline Trichilia quadrijuga Kunth & 2 & 6 \\
\hline \multicolumn{3}{|l|}{ MORACEAE } \\
\hline Brosimum acutifolium Huber & 1 & - \\
\hline Brosimum guianense (Aubl.) Huber & 23 & 17 \\
\hline Brosimum parinarioides Ducke & 1 & - \\
\hline Brosimum rubescens Taub. & 1 & - \\
\hline Clarisia ilicifolia (Spreng.) Lanj. \& Rossberg & 1 & - \\
\hline Ficus maxima Mill. & - & 1 \\
\hline Ficus pertusa L. f. & - & 1 \\
\hline Helicostylis tomentosa (Poepp. \& Endl.) Rusby & 1 & 2 \\
\hline Maquira calophylla (Poepp. \& Endl.) C.C. Berg & - & 1 \\
\hline Maquira guianensis Aubl. & 5 & 4 \\
\hline Perebea mollis (Poepp. \& Endl.) Huber & 1 & - \\
\hline Pseudolmedia murure Standl. & 1 & 3 \\
\hline \multicolumn{3}{|l|}{ MYRISTICACEAE } \\
\hline Iryanthera laevis Markgr. & - & 1 \\
\hline Virola surinamensis (Rol. ex Rottb.) Warb. & 8 & 10 \\
\hline \multicolumn{3}{|l|}{ MYRTACEAE } \\
\hline Eugenia anastomosans DC. & 2 & 2 \\
\hline Eugenia brachypoda DC. & 1 & - \\
\hline Eugenia cupulata Amshoff & - & 1 \\
\hline Eugenia deflexa Poir. & 2 & - \\
\hline Eugenia egensis DC. & 1 & - \\
\hline Eugenia feijoi $\mathrm{O}$. Berg & 1 & 1 \\
\hline Eugenia flavescens DC. & 22 & 50 \\
\hline Eugenia lambertiana DC. & 4 & 1 \\
\hline Eugenia omissa Mc Vaugh & 20 & 25 \\
\hline Eugenia patrisii Vahl & 2 & 9 \\
\hline Myrcia eximia DC. & 2 & - \\
\hline Myrcia guianensis (Aubl.) DC. & 1 & 4 \\
\hline Myrciaria floribunda (H. West ex Willd.) O. Berg & 1 & 4 \\
\hline
\end{tabular}


Appendix 1. Continued...

\begin{tabular}{|c|c|c|}
\hline \multirow{2}{*}{ Family/Specie } & \multicolumn{2}{|c|}{ Number of individuals sampled } \\
\hline & Undisturbed forests & Disturbed forests \\
\hline \multicolumn{3}{|l|}{ NYCTAGINACEAE } \\
\hline Guapira opposita (Vell.) Reitz & - & 1 \\
\hline \multicolumn{3}{|l|}{ OCHNACEAE } \\
\hline Lacunaria crenata (Tul.) A.C. Sm. & 1 & - \\
\hline Ouratea paraensis Huber & - & 1 \\
\hline \multicolumn{3}{|l|}{ OLACACEAE } \\
\hline Cathedra acuminata (Benth.) Miers & 12 & 11 \\
\hline Chaunochiton kappleri (Sagot ex Engl.) Ducke & 2 & - \\
\hline Dulacia candida (Poepp.) Kuntze & 2 & - \\
\hline Heisteria acuminata (Bonpl.) Engl. & - & 1 \\
\hline Minquartia guianensis Aubl. & 5 & - \\
\hline \multicolumn{3}{|l|}{ OPILIACEAE } \\
\hline Agonandra brasiliensis Miers ex Benth. \& Hook. f. & - & 1 \\
\hline \multicolumn{3}{|l|}{ POLYGONACEAE } \\
\hline Coccoloba latifolia Lam. & 8 & 6 \\
\hline \multicolumn{3}{|l|}{ RUBIACEAE } \\
\hline Alibertia edulis (Rich.) A. Rich. ex DC. & 2 & 1 \\
\hline Botryarrhena pendula Ducke & 1 & 4 \\
\hline Genipa americana $\mathrm{L}$. & - & 2 \\
\hline Isertia hypoleuca Benth. & - & 1 \\
\hline Posoqueria latifolia (Rudge) Roem \& Schoolt & 3 & 19 \\
\hline Posoqueria longiflora Aubl. & 1 & 1 \\
\hline \multicolumn{3}{|l|}{ RUTACEAE } \\
\hline Galipea trifoliata Aubl. & 1 & 8 \\
\hline \multicolumn{3}{|l|}{ SALICACEAE } \\
\hline Casearia decandra Jacq. & - & 1 \\
\hline Casearia grandiflora Cambess. & - & 1 \\
\hline Casearia pitumba Sleumer & 1 & 1 \\
\hline Casearia ulmifolia Vahl ex Vent. & 1 & - \\
\hline \multicolumn{3}{|l|}{ SAPINDACEAE } \\
\hline Cupania scrobiculata Rich. & 1 & - \\
\hline Talisia veraluciana Guarim & 1 & 1 \\
\hline Toulicia guianensis Aubl. & 2 & 7 \\
\hline \multicolumn{3}{|l|}{ SAPOTACEAE } \\
\hline Chrysophyllum cuneifolium (Rudge) A. DC. & 3 & - \\
\hline Chrysophyllum sparsiflorum Klotzsch ex Miq. & - & 3 \\
\hline Ecclinusa abbreviata Ducke & 1 & - \\
\hline Manilkara huberi (Ducke) A. Chev. & 1 & 3 \\
\hline Micropholis acutangula (Ducke) Eyma & 3 & 2 \\
\hline Micropholis guyanensis (A. DC.) Pierre & 6 & 1 \\
\hline Micropholis venulosa (Mart. \& Eichler) Pierre & 5 & 9 \\
\hline Pouteria caimito (Ruiz \& Pav.) Radlk. & 1 & 2 \\
\hline Pouteria decorticans T.D. Penn. & 1 & 2 \\
\hline Pouteria glomerata (Miq.) Radlk. & 1 & - \\
\hline Pouteria gongrijpii Eyma & 1 & 10 \\
\hline Pouteria guianensis Aubl. & 11 & 13 \\
\hline Pouteria macrophylla (Lam.) Eyma & 1 & 1 \\
\hline Pouteria robusta (Mart. \& Eichler) Eyma & 1 & 3 \\
\hline Pouteria venosa (Mart.) Baehni & 2 & 1 \\
\hline
\end{tabular}


Appendix 1. Continued...

Family/Specie

Pradosia granulosa Pires \& T.D. Penn.

Sarcaulus brasiliensis (A. DC.) Eyma

SIMAROUBACEAE

Simaba cedron Planch.

Simaba polyphylla (Cavalcante) W.W. Thomas

Simarouba amara Aubl.

SIPARUNACEAE

Siparuna guianensis Aubl.

ULMACEAE

Ampelocera edentula Kuhlm.

URTICACEAE

Cecropia distachya Huber

Cecropia obtusa Trécul

Cecropia sciadophylla Mart.

Pourouma guianensis Aubl.

Pourouma mollis Trécul

VIOLACEAE

Amphirrhox surinamensis Eichler

Rinorea guianensis Aubl.

Rinorea passoura Kuntze

Rinorea riana Aubl.

VOCHYSIACEAE

Qualea acuminata Spruce ex Warm.

Ruizterania albiflora (Warm.) Marc.-Berti

Vochysia vismiifolia Spruce ex Warm.
Number of individuals sampled Undisturbed forests Disturbed forests

13

2

6

$-$

4

1

9

8

2

2

12

1

- 2

- 1

1

$\begin{array}{ll}- & 1\end{array}$

$4 \quad 1$

- 2

$6 \quad 3$

45

$\begin{array}{ll}- & 2 \\ - & 2 \\ - & -2\end{array}$

- 3

$4 \quad 14$ 